\title{
Use of Protein G Microcolumns in Chromatographic Immunoassays: A Comparison of Competitive Binding Formats
}

\author{
Erika L. Pfaunmiller, Jeanethe A. Anguizola, Mitchell L. Milanuk, \\ NaTasha Carter, and David S. Hage*
}

Chemistry Department

University of Nebraska

Lincoln, NE

*Author for correspondence: 704 Hamilton Hall, Chemistry Department, University of

Nebraska, Lincoln, NE 68588-0304 USA. Phone: 402-472-2744; FAX: 402-472-9402; Email:

dhage1@unl.edu 


\begin{abstract}
Affinity microcolumns containing protein $G$ were used as general platforms for creating chromatographic-based competitive binding immunoassays. Human serum albumin (HSA) was used as a model target for this work and HSA tagged with a near infrared fluorescent dye was utilized as the label. The protein G microcolumns were evaluated for use in several assay formats, including both solution-based and column-based competitive binding immunoassays and simultaneous or sequential injection formats. All of these methods were characterized by using the same amounts of labeled HSA and anti-HSA antibodies per sample, as chosen for the analysis of a protein target in the low-to-mid $\mathrm{ng} / \mathrm{mL}$ range. The results were used to compare these formats in terms of their response, precision, limits of detection, and analysis time. All these methods gave detection limits in the range of $8-19 \mathrm{ng} / \mathrm{mL}$ and precisions ranging from \pm $5 \%$ to $\pm 10 \%$ when using an injection flow rate of $0.10 \mathrm{~mL} / \mathrm{min}$. The column-based sequential injection immunoassay provided the best limit of detection and the greatest change in response at low target concentrations, while the solution-based simultaneous injection method had the broadest linear and dynamic ranges. These results provided valuable guidelines that can be employed to develop and extend the use of protein $\mathrm{G}$ microcolumns and these competitive binding formats to other protein biomarkers or biological agents of clinical or pharmaceutical interest.
\end{abstract}

Key words: Chromatographic immunoassay; Affinity microcolumn; Protein G; Competitive binding immunoassay; Human serum albumin 


\section{Introduction}

Antibodies and related agents, such as $\mathrm{F}_{\mathrm{ab}}$ fragments, have been used for many years for the selective and sensitive detection of analytes in a variety of samples [1-4]. Over the last few decades there has been ongoing interest in combining these selective binding agents with chromatographic systems, giving a method known as a chromatographic immunoassay or flowinjection immunoanalysis [5-11]. Chromatographic immunoassays have been explored in many previous studies for the analysis of proteins, drugs, hormones, and other targets [5,6,8-11]. These assays have been utilized in numerous formats and have been combined with detection methods that have included absorbance, fluorescence, chemiluminescence and electrochemical detection, as well as enzyme-based detection and mass spectrometry [6-11]. Chromatographic immunoassays can be fast and relatively easy to automate when they are used as part of an HPLC system [5,6,8], and these methods can be employed with samples such as serum, plasma, urine, cerebrospinal fluid, and food $[8,10,11]$.

Many chromatographic immunoassays involve the covalent immobilization of an antibody or a related binding agent to a support that is suitable for use in a column [5,8-11,12]. However, a chromatographic immunoassay can also be carried out by adsorbing antibodies to a support that contains protein $\mathrm{G}$ as a secondary binding agent [6,9-11]. Protein $\mathrm{G}$ is a bacterial cell wall protein produced by groups $\mathrm{C}$ and $\mathrm{G}$ streptococci and that has the ability to bind at the $F_{c}$ region of many immunoglobulins [13-15]. This results in adsorbed antibodies that have a good orientation and high activity for binding to their target compounds [9,14-16]. The ability of protein $\mathrm{G}$ to bind many types of immunoglobulins also makes this agent of interest in creating general platforms that can be used with a wide range of antibodies, targets and samples [6,9-11]. For instance, protein $\mathrm{G}$ has already been used in a number of chromatographic immunoassays to measure analytes in complex samples such as serum, food, and cell lysates [17-23]. In addition, 
antibodies that are adsorbed to protein $\mathrm{G}$ can later be released under relatively mild acidic conditions, and the protein $\mathrm{G}$ can be regenerated by placing it back into a neutral buffer $[9,14]$. This last feature makes protein $G$ columns valuable in assays where good run-to-run reproducibility is required and/or frequent replacement of the adsorbed antibodies is desired $[6,9,10,14]$.

Another area of interest in chromatographic immunoassays is the use of miniaturized columns, capillaries or microchips to carry out such methods [17-21,24-32]. This type of work has included the utilization of protein $G$, or the related agent protein $A$, in such techniques [17,19-23,32-37]. One approach for creating small-scale chromatographic immunoassays is to use affinity microcolumns, which are columns that contain biologically-related binding agents (e.g., immobilized antibodies) and which have volumes in the low microliter range [29,38]. Advantages to using affinity microcolumns in chromatographic immunoassays include the small amounts of antibodies or binding ligands that are required, the low non-specific binding of these columns for sample components, and their short residence times, with the latter often allowing analysis times of only a few minutes [29,38].

This study examined the development of affinity microcolumns containing protein $\mathrm{G}$ and the use of these microcolumns in chromatographic immunoassays based on several competitive binding formats (see Figs. 1-3). Human serum albumin (HSA) was used as a model protein and target for this work and a near infrared fluorescent tag was used as the label $[39,40]$. Competitive binding formats that were considered included both solution- and column-based simultaneous injection assays and a column-based sequential immunoassay format $[8,10]$. These formats were used under similar chromatographic conditions and compared in terms of their response, precision, limits of detection, and total assay time. The results were used to provide general guidelines regarding the behavior of these methods, as well as information on the relative 
advantages and disadvantages of each approach. This information should be useful in selecting assay formats in future work with protein G microcolumns and in extending this approach to the analysis of other protein biomarkers, biological agents, or target compounds.

\section{Experimental}

\subsection{Reagents}

Nucleosil Si-1000 (1000 ̊̊ pore size, $7 \mu \mathrm{m}$ particle size) was purchased from MachereyNagel (Bethlehem, PA, USA). The HSA (Cohn fraction V, essentially fatty acid free, $\geq 96 \%$ pure), sodium cyanoborohydride (94\%, a mild reducing agent), sodium borohydride (98\%, a strong reducing agent), periodic acid (> 99\%, an oxidizing agent), Tween-20 (polyethylene glycol sorbitan monolaurate), and rabbit immunoglobulin $\mathrm{G}$ (rabbit $\mathrm{IgG}$, > 95\%) were from Sigma-Aldrich (St. Louis, MO, USA). IRDye 800CW $N$-hydroxysuccinimide (NHS) ester was obtained from LI-COR (Lincoln, NE, USA). Polyclonal anti-HSA antibodies (rabbit) were

obtained from Rockland Immunochemicals (Gilbertsville, PA, USA). Reagents for the bicinchoninic acid (BCA) protein assay and the protein $\mathrm{G}$ (recombinant, albumin binding domains removed) were from Pierce (Rockford, IL, USA). All buffers and aqueous solutions were prepared using water from an EMD MILLI-Q system and were filtered using $0.2 \mu \mathrm{m}$ GNWP nylon filters, both of which were from Millipore (Billerica, MA, USA).

\subsection{Apparatus}

A Jasco 2000 HPLC system (Easton, MD, USA) was used in these experiments. This system consisted of three DG-2080-53 solvent degassers, two PU-2080 isocratic pumps, an AS2057 autosampler equipped with a $100 \mu \mathrm{L}$ sample loop (operated in the partial loop injection mode), a UV-2075 absorbance detector, and a FP-2020 fluorescence detector. This system also included a custom-built near infrared fluorescence detector [26,39] that was provided by LI- 
COR. The temperature of the columns was controlled by using an on-line column heater. A Rheodyne Advantage PF six-port switching valve (Cotati, CA, USA) was used for alternating passage of the analyte and buffer solutions through the columns during the frontal analysis studies. The system components were controlled by a Jasco LC-Net II/ADC system and ChromNAV software v1.18.03 (Easton, MD, USA). Chromatographic data were collected using ChromNAV and processed using PeakFit 4.12 (SeaSolve Software, San Jose, CA, USA). Purification of the labeled HSA was performed using Zeba spin columns (7 kDa MW cutoff, 0.7 to $4 \mathrm{~mL}$ sample capacity) from Pierce, along with a 5702RH temperature-controlled centrifuge from Eppendorf (New York, NY, USA) and a fixed-angle centrifuge rotor from VWR (West Chester, PA, USA). The microcolumns were packed using an HPLC slurry packing system from ChromTech (Apple Valley, MN, USA).

\subsection{Preparation of protein $G$ microcolumns}

Nucleosil Si-1000 silica was converted into a diol-bonded form, with this material then being oxidized with periodic acid and placed into an aldehyde-activated form for use in the Schiff base immobilization method, as described previously [5,12]. Prior to its use in activation or immobilization, the silica was placed into the appropriate reaction buffer and sonicated under vacuum for $5 \mathrm{~min}$. Approximately $3 \mathrm{mg}$ of protein $\mathrm{G}$ per $100 \mathrm{mg}$ of aldehyde-activated silica was placed into an immobilization buffer that contained $\mathrm{pH} 6.0,0.10 \mathrm{M}$ potassium phosphate and $100 \mathrm{mg} / \mathrm{mL}$ sodium cyanoborohydride. This protein/silica slurry was then shaken at $4^{\circ} \mathrm{C}$ for 3 days. After completion of the immobilization reaction, the protein $\mathrm{G}$ support was washed using $\mathrm{pH}$ 8.0, 0.10 M potassium phosphate buffer. A $2 \mathrm{mg} / \mathrm{mL}$ solution of sodium borohydride in $\mathrm{pH} 8.0,0.10 \mathrm{M}$ potassium phosphate buffer was then added to this support, and the mixture was shaken at room temperature for $90 \mathrm{~min}$. The final support was washed with $\mathrm{pH} 7.4,0.067 \mathrm{M}$ 
potassium phosphate buffer and stored in this buffer at $4^{\circ} \mathrm{C}$ until use. A control support was prepared in the same manner, but with no protein $\mathrm{G}$ being added during the immobilization step.

The amount of immobilized protein on each support was determined in triplicate by a BCA protein assay [41], using protein $\mathrm{G}$ as the standard and the control support as the blank. The protein G silica and control support were downward slurry packed at 4000 psi (28 MPa) into separate $2.1 \mathrm{~mm}$ i.d. $\times 5 \mathrm{~mm}$ stainless steel columns using $\mathrm{pH}$ 7.4, 0.067 M potassium phosphate buffer as the packing solution. These columns were stored in the same buffer at $4^{\circ} \mathrm{C}$ when not in use and were stable for up to one year, with some columns being used over approximately 200 application and elution cycles.

\subsection{Preparation of labeled HSA}

A $0.10 \mathrm{mg}$ portion of IRDye $800 \mathrm{CW}$ NHS ester was dissolved in $20 \mu \mathrm{L}$ water and a 10 $\mu \mathrm{L}$ aliquot of this solution was combined with $1 \mathrm{~mL}$ of a $1 \mathrm{mg} / \mathrm{mL}$ HSA solution in $\mathrm{pH} 8.5,0.10$ $\mathrm{M}$ potassium phosphate buffer. This solution was mixed and allowed to shake for $2 \mathrm{~h}$ in the dark at room temperature. A Zeba spin column was utilized with $\mathrm{pH} 7.4,0.067 \mathrm{M}$ potassium phosphate buffer to remove any unreacted dye from the labeled HSA. Absorbance measurements were made at 780 and $280 \mathrm{~nm}$ to determine the dye/protein ratio and protein concentration of the final labeled HSA solution. The labeled HSA solution had a final concentration of 0.8-0.9 $\mathrm{mg} \mathrm{HSA} / \mathrm{mL}$ and a dye/protein ratio of 1.0-2.0, as determined over five batches of this conjugate. The labeled HSA solutions were stored at $4^{\circ} \mathrm{C}$ in $\mathrm{pH} 7.4,0.067 \mathrm{M}$ potassium phosphate buffer when not in use. The labeled HSA was stable for up to 2 weeks when protected from light and stored under these conditions. The near infrared fluorescent labeled HSA was detected in the chromatographic systems by using an excitation wavelength of $774 \mathrm{~nm}$ and an emission wavelength of $789 \mathrm{~nm}$. 


\subsection{Evaluation of protein $G$ microcolumns}

Rabbit IgG was used in frontal analysis experiments to determine the active amount of protein $\mathrm{G}$ that was in the affinity microcolumns $[9,13-15,38]$. In these experiments, $\mathrm{pH} 7.4$, $0.067 \mathrm{M}$ potassium phosphate buffer was applied to a protein $\mathrm{G}$ microcolumn at $0.50 \mathrm{~mL} / \mathrm{min}$ for $1 \mathrm{~min}$, followed by application of $0.05 \mathrm{mg} / \mathrm{mL}$ rabbit $\operatorname{IgG}$ in the same buffer at $0.10 \mathrm{~mL} / \mathrm{min}$. The elution of the rabbit IgG was monitored at $280 \mathrm{~nm}$. After a breakthrough curve had been obtained, a pH 2.5, $0.067 \mathrm{M}$ potassium phosphate buffer was passed through the protein $\mathrm{G}$ microcolumn at $0.50 \mathrm{~mL} / \mathrm{min}$ for $10 \mathrm{~min}$ to elute the retained rabbit IgG [42]. This cycle was repeated as needed. The mean location of each breakthrough curve was determined by using a Savitzky-Golay first derivative algorithm for smoothing, followed by fitting of the first derivative to an exponentially-modified Gaussian curve and determination of the central moment. The same approach was employed with a control column to correct for the void time of the system and non-specific binding of rabbit $\operatorname{IgG}$ to the support or system components. The level of non-specific binding was negligible for rabbit $\operatorname{IgG}$, as has been noted for the same analyte on comparable protein $\mathrm{G}$ columns [15,42].

The binding of the protein $\mathrm{G}$ microcolumns to small amounts of antibodies was evaluated by using samples containing various concentrations of anti-HSA antibodies (e.g., $1.67 \mu \mathrm{g} / \mathrm{mL}$ ) that were mixed in a 15:1 (v/v) ratio with a fixed amount of labeled HSA (initial concentration, $1200 \mathrm{ng} / \mathrm{mL}$; concentration in mixture, $80 \mathrm{ng} / \mathrm{mL}$ ) and incubated for 30 min prior to injection. A series of $50 \mu \mathrm{L}$ injections for each mixture were then made onto a protein $\mathrm{G}$ microcolumn at 0.10 $\mathrm{mL} / \mathrm{min}$ and in the presence of a $\mathrm{pH} 7.4,0.067 \mathrm{M}$ potassium phosphate buffer containing $0.01 \%$ Tween 20. The relative capture efficiency was determined by comparing the areas of these peaks to the total areas that were obtained for the same samples on a control column. 


\subsection{Chromatographic immunoassays}

The final application buffer for each assay format used in this study was $\mathrm{pH} 7.4,0.067 \mathrm{M}$ potassium phosphate buffer that contained $0.01 \%$ Tween 20 . The flow rate used for sample

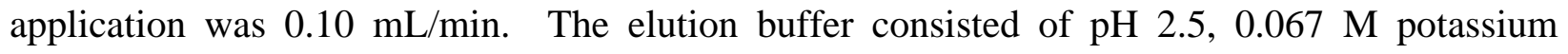
phosphate buffer, and the elution flow rate was $0.50 \mathrm{~mL} / \mathrm{min}$. The elution step for each assay was $10 \mathrm{~min}$ in length, after which the application buffer was reapplied for $20 \mathrm{~min}$ to regenerate the column prior to the next sample analysis [42]. The near infrared fluorescent label was detected by using an excitation wavelength of $774 \mathrm{~nm}$ and an emission wavelength of $789 \mathrm{~nm}$. All chromatographic studies were conducted at room temperature.

In the solution-based simultaneous injection immunoassay, the sample was mixed and incubated with a fixed amount of antibodies and a labeled analog of the target (i.e., labeled HSA, or the "label") prior to injection onto a protein G microcolumn. The general format that was used for this assay is shown in Fig. 1. The concentration of the anti-HSA antibodies prior to mixing was $5.0 \mu \mathrm{g} / \mathrm{mL}$, the concentration of the labeled HSA was $240 \mathrm{ng} / \mathrm{mL}$, and the samples contained $0-400 \mathrm{ng} / \mathrm{mL}$ HSA. These reagents were combined in a 1:1:1 volume ratio, using 0.5 $\mathrm{mL}$ of each reagent. This mixture was allowed to incubate at room temperature for at least 30 min. A series of $50 \mu \mathrm{L}$ injections of this mixture were then made onto the protein $\mathrm{G}$ microcolumn, with an elution step being conducted after every three injections.

In the column-based simultaneous injection immunoassay, only the sample and labeled analog of the target (i.e., labeled HSA) were pre-mixed prior to injection, as illustrated in Fig. 2. In this format, the antibodies were applied to the protein $G$ microcolumn before the sample/labeled analog mixture was injected. In this study, a $50 \mu \mathrm{L}$ injection containing 1.67 $\mu \mathrm{g} / \mathrm{mL}$ of anti-HSA antibodies was first made onto a protein $\mathrm{G}$ microcolumn at $0.10 \mathrm{~mL} / \mathrm{min}$. A 
$0.75 \mathrm{~mL}$ portion of $160 \mathrm{ng} / \mathrm{mL}$ labeled HSA was then combined with a $0.75 \mathrm{~mL}$ sample containing 0-400 ng/mL HSA and $50 \mu \mathrm{L}$ injections of this mixture were applied to the protein $\mathrm{G}$ column that contained the adsorbed anti-HSA antibodies. An elution and regeneration step was carried out either after each sample injection or after three replicate injections of a sample had been applied to the column.

In the column-based sequential injection format, the antibodies, sample, and labeled analog were injected separately and in series, as shown in Fig. 3. For each analysis, a $50 \mu \mathrm{L}$ injection of $1.67 \mu \mathrm{g} / \mathrm{mL}$ anti-HSA antibodies was made at $0.10 \mathrm{~mL} / \mathrm{min}$, followed at the same flow rate by a $50 \mu \mathrm{L}$ injection of a sample containing $0-400 \mathrm{ng} / \mathrm{mL}$ HSA and a $50 \mu \mathrm{L}$ injection containing $80 \mathrm{ng} / \mathrm{mL}$ of the labelled HSA. This sequence was followed by an elution and regeneration step and was repeated in triplicate for each sample.

\section{Results and Discussion}

\subsection{Preparation and characterization of protein $G$ support}

The protein G microcolumns were prepared by first converting HPLC-grade $7 \mu \mathrm{m}$ diameter silica into a diol-bonded form. This type of support was employed because of its good mechanical stability and efficiency, the ease with which this material can be modified for protein attachment, and the low non-specific binding of diol-bonded silica for many biological compounds $[9,15,29]$. The Schiff base immobilization method was used with this material because it has been shown to provide higher activities for protein $G$ and similar ligands (e.g., protein A) when compared to other common amine-based coupling methods $[12,14,15,33]$.

Silica with a pore size of $1000 \AA$ was employed to allow sufficient room for the immobilization of protein G, the binding of this ligand to antibodies, and the interaction of these antibodies with 
HSA. However, supports with smaller pore sizes (e.g., 50-500 ̊̊) can allow up to two-fold more IgG-class antibodies to be bound to immobilized protein $\mathrm{G}$ per gram of the support [15].

The protein G supports that were made in this report contained $6.1( \pm 0.4) \mathrm{mg}$ protein $\mathrm{G} / \mathrm{g}$ silica. Based on a molecular weight for protein $\mathrm{G}$ of roughly $32 \mathrm{kDa}$ [14], this content corresponded to $0.19( \pm 0.01) \mu \mathrm{mol}$ protein G/g silica and a surface coverage of $0.24( \pm 0.02) \mathrm{mg}$ protein $\mathrm{G} / \mathrm{m}^{2}$ silica, or $0.011( \pm 0.005) \mu \mathrm{mol}$ protein $\mathrm{G} / \mathrm{m}^{2}$ silica. These results were in same general range as has been observed previously for comparable materials (e.g., a maximum protein $\mathrm{G}$ content of $20.6( \pm 1.1) \mathrm{mg} / \mathrm{g}$ silica, as noted in Ref. [15]).

Frontal analysis using rabbit IgG as the applied target indicated that the protein $G$ columns had an overall binding capacity of $8.7( \pm 1.0) \mathrm{mg} \mathrm{IgG/g}$ silica. This corresponded to a total binding capacity of approximately $0.067( \pm 0.020) \mathrm{mg} \operatorname{IgG}$ for a $2.1 \mathrm{~mm}$ i.d. $\times 5 \mathrm{~mm}$ protein G microcolumn. The specific activity of these microcolumns (i.e., the relative amount of active protein $\mathrm{G}$ ) was $31 \%$. This result agreed with previous work utilizing similar protein $\mathrm{G}$ supports, which have had specific activities in the range of $30-47 \%[15,42]$. The stability of the protein $\mathrm{G}$ microcolumns was also examined by using a series of frontal analysis experiments over the course of 20-50 application and elution cycles. These data indicated that only a $0.3-0.9 \%$ change in the binding capacity occurred from one application/elution cycle to the next.

\subsection{Retention and elution properties of protein $G$ microcolumns}

The ability of the protein G microcolumns to bind small amounts of antibodies, such as might be used in a competitive binding chromatographic immunoassay, was next examined. This was done by injecting mixtures containing representative concentrations of anti-HSA antibodies that had been incubated with a fixed amount of labeled HSA. Of particular interest was the behavior of samples that contained around $84 \mathrm{ng}$ of anti-HSA antibodies (e.g., 1.67 
$\mu \mathrm{g} / \mathrm{mL}$ in a $50 \mu \mathrm{L}$ sample), which was the approximate amount of antibodies that were used per injection in the chromatographic immunoassays that are described later in this report. This amount of antibodies had an average capture efficiency of $92( \pm 5) \%$ on the protein $\mathrm{G}$ microcolumns at an application flow rate of $0.10 \mathrm{~mL} / \mathrm{min}$. No significant increase in this capture efficiency was noted at the $95 \%$ confidence level when the flow rate was reduced to 0.01 $\mathrm{mL} / \mathrm{min}$. However, the capture efficiency did decrease by $25-30 \%$ as the flow rate was increased to $1.0 \mathrm{~mL} / \mathrm{min}$.

This last effect, in which a decrease in binding is noted at higher flow rates, has been noted in prior work with small affinity columns containing immobilized protein $\mathrm{G}$ or protein A (i.e., a related binding agent for antibodies) $[33,34,43,44]$. This type of behavior has been previously shown to be due to the presence of slow adsorption kinetics and/or slow mass transfer [33]. These conditions, in turn, can lead to a lower probability for binding by the applied antibodies as a higher flow rate and smaller sample residence time are used to inject samples onto the column $[33,34,43,44]$.

The elution time for the non-retained peak in these studies was also of interest because monitoring the amount of the non-retained target analog (e.g., labeled HSA) is one way of following the response of a competition-based chromatographic immunoassay [10,11]. The nonretained peak for the protein $\mathrm{G}$ microcolumns eluted within $3.5 \mathrm{~min}$ at $0.10 \mathrm{~mL} / \mathrm{min}$ (see Fig. 4), with this value increasing to $6.8 \mathrm{~min}$ at $0.05 \mathrm{~mL} / \mathrm{min}$ and decreasing to $0.35 \mathrm{~min}$ at $1.0 \mathrm{~mL} / \mathrm{min}$. The average back pressure across each protein $\mathrm{G}$ microcolumn was less than 100 psi for flow rates up to $1.0 \mathrm{~mL} / \mathrm{min}$. At a flow rate of $0.10 \mathrm{~mL} / \mathrm{min}$ or less, the back pressure was below 50 psi. As a compromise between capture efficiency, assay speed and column back pressure, an application flow rate of $0.10 \mathrm{~mL} / \mathrm{min}$ was used in the remainder of this report. 


\subsection{Use of protein $\mathrm{G}$ microcolumns in a solution-based simultaneous injection immunoassay}

One format for a chromatographic competitive binding immunoassay that was examined was a solution-based simultaneous injection method. This approach was a modified version of a standard solution-phase competitive binding immunoassay [1-3]. In this method, a protein $\mathrm{G}$ column was used to separate the bound and free fractions of the labeled target analog (or "label") after the label and target had been allowed to compete in solution for binding to a small amount of antibodies against the target [36].

The general scheme that was used for such a method is illustrated in Fig. 1. The first step involved incubation of the sample, a fixed amount of the label, and a limited amount of antibodies. After being allowed to react in solution (e.g., for $30 \mathrm{~min}$ in this study), the mixture was injected onto a protein $\mathrm{G}$ microcolumn, to which the antibody-label and antibody-target complexes were allowed to bind. Based on the competition that had already occurred between the target and label for the antibodies, the non-retained fraction for the label was then used to provide an indirect measurement of the amount of target in the original sample. After the peak due to the non-retained label had been measured for one or more injections, an elution buffer was used to release the retained components and the column was regenerated before making another series of injections.

In this report, a solution-based simultaneous injection immunoassay for HSA was carried out by first combining the anti-HSA antibodies with the labeled HSA and a sample containing HSA. A $50 \mu \mathrm{L}$ injection of this mixture was then made onto a protein $\mathrm{G}$ microcolumn. A typical calibration curve for this assay is shown in Fig. 5(a), as obtained with an injection flow rate of $0.10 \mathrm{~mL} / \mathrm{min}$. The lower limit of detection was $19 \mathrm{ng} / \mathrm{mL}(S / N=3)$, and the assay results had a precision of less than or equal to $\pm 10 \%$ over the entire calibration range. The linear range of this method extended up to about $225 \mathrm{ng} / \mathrm{mL}$, and the dynamic range went up to around 400 
$\mathrm{ng} / \mathrm{mL}$. Results based on the non-retained peak were obtained within 3.5-5.0 min of injecting the antibody/label/sample mixture at $0.10 \mathrm{~mL} / \mathrm{min}$. This gave an assay time, including the half-hour incubation step, of around 34-35 min.

It was possible in this format to make multiple injections onto a protein $\mathrm{G}$ column prior to elution of the retained components. This feature can be useful in helping to increase the throughput of this method in work with large batches of samples. However, care must be exercised in using this approach on a protein $\mathrm{G}$ microcolumn and with a solution-based competitive binding immunoassay because the capture efficiency will decrease and the response based on the non-retained peak will increase slightly when no elution step is used between injections, as is illustrated in Fig. 6. The decrease in capture efficiency occurs because a greater total load of the antibody is being applied to the column with each additional injection $[43,44]$. This lower capture efficiency, in turn, leads to a greater response based on the non-retained peak because more of the antibody-label complex is now eluting in the non-retained fraction. In this study, up to three replicate injections of a given sample/reagent mixture were made prior to applying the elution buffer; this provided stable results while also minimizing the overall analysis time.

The response of this format is affected by the same factors that determine the behavior of a traditional solution-phase competitive binding immunoassay [1-3,36]. These factors include the concentrations of the label and antibodies that are combined with the sample, the affinity of these antibodies for the target and the label, and the incubation time that is allowed for these components to react [1-3]. For instance, Fig. 6 shows how an increase in the amount of antibodies led to greater binding by these antibodies to the label and a lower signal for the nonretained portion of the label. However, the use of more antibodies also increased the cost of the assay and required a greater concentration of the target to produce a change in the response, 
which lead to a higher limit of detection. For the sake of comparison, the amounts of the label and antibodies that were used in this report were kept the same from one assay format to the next and were chosen to provide a usable assay response in the low-to-mid $\mathrm{ng} / \mathrm{mL}$ range for the target.

Other parameters that were important in this assay format when using a protein $G$ microcolumn were the relative binding capacity of this column and its capture efficiency for antibodies [10,33,34]. These parameters were initially evaluated in Sections 3.1-3.2 in terms of the overall behavior of the protein $\mathrm{G}$ microcolumns. As an example, the measured binding capacity of $0.067 \mathrm{mg}$ IgG for a $2.1 \mathrm{~mm}$ i.d. $\times 5 \mathrm{~mm}$ protein $\mathrm{G}$ microcolumn was about 800 -fold greater than the $84 \mathrm{ng}$ of antibodies that were applied during one injection in the solution-based simultaneous injection immunoassay. It was again noted that the capture efficiency of $92 \%$ for such a sample at $0.10 \mathrm{~mL} / \mathrm{min}$ was affected by a change in the application flow rate. For instance, if the elution time for the non-retained peak in the solution-based simultaneous injection immunoassay was reduced by five-fold in going from an injection flow rate of 0.10 to $0.50 \mathrm{~mL} / \mathrm{min}$, the higher flow rate also lead to a loss of about $15 \%$ in the capture efficiency. This decrease in capture efficiency produced a higher response for standards containing only the labeled HSA and anti-HSA antibodies (i.e., due to less efficient capture of the antibody-label complex), as well as a calibration curve with a smaller slope. The result was a higher limit of detection. The same relative changes in the capture efficiency and response, as well as a shift to higher limits of detection, were also noted at higher flow rates in the other assay formats that were examined in this report.

\subsection{Use of protein G microcolumns in a column-based simultaneous injection immunoassay}

The second assay format that was evaluated for use with the protein $\mathrm{G}$ microcolumns was a column-based simultaneous injection immunoassay [8-11,22,23,35-37]. This method is 
illustrated in Fig. 2, and had the antibodies being adsorbed to the protein $\mathrm{G}$ microcolumn before the label and the target were applied. The label and target were pre-mixed prior to injection and applied to the column simultaneously, with no incubation step being required. The label and target in this format competed for the limited number of binding sites that were present on the adsorbed antibodies within the column. The rest of the steps in this format were the same as those in the solution-based simultaneous injection immunoassay.

A column-based simultaneous injection immunoassay was conducted by using the same amounts of antibodies and labeled HSA as utilized in Section 3.3 for the solution-based method. An example of a calibration plot that was generated with this assay at $0.10 \mathrm{~mL} / \mathrm{min}$ is given in Fig. 5(b). The lower limit of detection was $13 \mathrm{ng} / \mathrm{mL}(S / N=3)$, and the precision obtained for triplicate injections at each sample concentration was $\pm 5 \%$ over the entire concentration range that was examined. Some curvature in the response was seen above $75-80 \mathrm{ng} / \mathrm{mL} \mathrm{HSA}$, and the dynamic range extended to a little over $250 \mathrm{ng} / \mathrm{mL}$. Both this linear region and dynamic range were narrower than noted in Fig. 5(a) for a solution-based simultaneous injection immunoassay that made use of the same reagents. This was likely due to the much shorter time that was allowed for competition and binding of the HSA and labeled HSA with the anti-HSA antibodies in the column-based method. In this column-based format, the incubation time was less than or equal to the microcolumn's void time at $0.10 \mathrm{~mL} / \mathrm{min}$, which was only $8-9$ s. However, Fig. 5(b) demonstrates that even these conditions resulted in a calibration curve that could be used for the measurement of HSA.

Results were obtained in this method in about 3.5-5.0 min after injection of the label and sample. However, the total assay time up to this point was now only $7-10 \mathrm{~min}$ at $0.10 \mathrm{~mL} / \mathrm{min}$. This was the time required for two sets of injections, spaced 3.5-5.0 min apart, for the application of the antibodies and labeled HSA/sample mixture. Unlike the solution-based simultaneous 
injection immunoassay, no pre-incubation step was required in the column-based method; however, an elution and regeneration step was now needed more frequently between sample injections. To obtain the most reproducible results, the elution and regeneration step was done after each sample injection; however, only a 3-5\% difference in the results were noted when up to three injections for the same sample were made prior to such a step. The elimination of the pre-incubation step and the manual procedures involved in such a step were important factors in leading to the improved precision of this column-based method over the solution-based approach. The better limit of detection that was obtained in the column-based method was further aided by this improvement in precision, along with the steeper response that was seen in this format at low target concentrations.

There are several parameters which can be varied to adjust the response in a columnbased simultaneous injection immunoassay $[10,22,23,35-37,45,46]$. These factors include the relative amounts of the label and antibodies that are used, the binding capacity of the column, the rate of the antibody-target/label interaction, and the injection flow rate [10,45,46]. For instance, as the injection flow rate was increased from $0.10 \mathrm{~mL} / \mathrm{min}$ to $0.50 \mathrm{~mL} / \mathrm{min}$ for the application of the label and HSA, the change in the capture efficiency by the anti-HSA antibodies decreased by approximately $10 \%$. Another factor to consider in such an assay when using a protein $\mathrm{G}$ microcolumn is the antibody capture efficiency. When the flow rate for adsorption of the antiHSA antibodies to the protein $\mathrm{G}$ microcolumn was increased from 0.10 to $0.50 \mathrm{~mL} / \mathrm{min}$, the capture efficiency for these antibodies decreased by $12 \%$.

\subsection{Use of protein G microcolumns in a column-based sequential injection immunoassay}

The third format evaluated for use with the protein $G$ microcolumns was a sequential injection immunoassay, as shown in Fig. 3. In this method, the sample and each of the reagents 
were applied to the protein G microcolumn independently. This format has not previously been reported in work with antibodies that have been adsorbed to protein $G$ or protein A supports; however, it has been used with antibodies that have been covalently immobilized to silica or other materials [8-11,45,47-51]. An important advantage of the sequential injection method is that the label and target/sample never come into contact with each other, which minimizes or eliminates any matrix effects the sample may have on the final response due to the label [10,51].

An example of a calibration plot that was generated in this format at an injection flow rate of $0.10 \mathrm{~mL} / \mathrm{min}$ is given in Fig. 5(c). The lower limit of detection under these conditions was $7.9 \mathrm{ng} / \mathrm{mL}(S / N=3)$, and the results had a typical relative precision of $\pm 5 \%$. The linear range for this method went up to about $50 \mathrm{ng} / \mathrm{mL}$ and the dynamic range extended up to around $150 \mathrm{ng} / \mathrm{mL}$. These features gave this approach the best limit of detection but the smallest linear and dynamic ranges seen in all of the assay formats that were examined. The better detection limit of this method was the combined result of its improved precision over the solution-based simultaneous injection immunoassay and its steeper response at low HSA concentrations versus both the solution- and column-based simultaneous injection immunoassays. The narrower linear and dynamic ranges seen in this format versus those for the solution-based simultaneous injection immunoassay were probably a result of the shorter time allowed in the column-based sequential injection method for competition of the HSA and labeled HSA for the anti-HSA antibodies. The steeper response and smaller linear/dynamic ranges versus the column-based simultaneous injection immunoassays were due to the target being allowed to contact and bind to the adsorbed antibodies before the label had been applied. The same trends have been noted when comparing these latter two methods for covalently immobilized antibodies $[45,46]$.

Results were obtained within about 3.5-5.0 min of injection for the label, and within 10.5$15.0 \mathrm{~min}$ of the application of antibodies to the protein G column. These times reflect the fact 
that each component of this method had to be independently applied to the protein $\mathrm{G}$ microcolumn. There was no need to have a pre-incubation period in this method, which helped to minimize the total analysis time per sample; however, elution and column regeneration steps were needed between each sample injection.

\subsection{Comparison of assays based on adsorbed antibodies versus immobilized antibodies}

A comparison was next made between the responses seen in Figs. 5(b-c) for antibodies adsorbed to protein $\mathrm{G}$ microcolumns and in prior work with column-based simultaneous or sequential injection immunoassays that used covalently immobilized anti-HSA antibodies $[45,46,51]$. One difference in these two groups of methods was in the amount of antibodies that was utilized. This issue in important to consider in that it can significantly affect the overall cost of the assay. With the protein $\mathrm{G}$ microcolumns, only $84 \mathrm{ng}$ (or $0.56 \mathrm{pmol}$ ) of antibodies were used per sample injection. In the prior work with immobilized antibodies, the equivalent of about $0.41 \mathrm{nmol}$ of active antibodies were present in $2.1 \mathrm{~mm}$ i.d. $\times 6.34 \mathrm{~mm}$ columns $[45,46,51]$. This was roughly a 730-fold difference in the amount of antibodies that was used per injection for the protein $G$ microcolumns versus the columns containing covalently immobilized antibodies. Even though the immobilized antibody columns from the previous studies were each used to examine many samples and standards, sometimes for up to hundreds of injections per column $[45,46,51]$, the net result was still a large decrease in the amount of antibodies that were required in the assays that employed protein $\mathrm{G}$ microcolumns.

The response obtained with the adsorbed versus covalently immobilized antibodies was

also considered. This was accomplished by comparing the calibration curves in Figs. 5(b-c) with the results that would be expected when using an equivalent amount of immobilized antibodies under the same flow rate conditions and using comparable amounts of the label $[45,46]$. These 
conditions included the use of a column that contained $0.56 \mathrm{pmol}$ of immobilized antibodies, an injection flow rate of $0.10 \mathrm{~mL} / \mathrm{min}$, and a label amount equal to $0.11 \mathrm{~mol}$ label $/ \mathrm{mol}$ antibody (i.e., the ratio obtained when mixing $4 \mathrm{ng}$ of labeled HSA with $84 \mathrm{ng}$ of anti-HSA antibodies). An association rate constant of $4.0 \times 10^{4} \mathrm{M}^{-1} \mathrm{~s}^{-1}$, as measured previously for HSA with immobilized anti-HSA antibodies [45,51], was also used to make this comparison.

It was found in this comparison that the responses seen in Fig. 5(b-c) were much narrower than those expected for covalently immobilized antibodies. During the use of antibodies that were adsorbed to protein $\mathrm{G}$ microcolumns, the dynamic ranges that were obtained for the column-based simultaneous and sequential injection formats covered about a 20 -fold range in concentration (i.e., in going from the lower limit of detection to the upper end of the dynamic range). In contrast to this, a dynamic range covering roughly a 60 - to 250 -fold change in concentration (i.e., in going from a 5\% to 95\% change in the response) would be expected for the same assay formats and under comparable conditions when using covalently immobilized antibodies [45].

Another difference in these two groups of methods was in the limits of detection that were obtained. The antibodies that were adsorbed to the protein $\mathrm{G}$ microcolumns gave detection limits that were more than 8 - to 10 -fold lower than would be expected when using covalently immobilized antibodies $[45,46,51]$. This difference, as well as the narrower dynamic ranges that were seen with the adsorbed antibodies, is most likely related to the differences in the distribution of the antibodies within the two types of columns. In the prior studies with covalently immobilized antibodies, these antibodies were spread uniformly throughout the length of the column. However, in the protein G microcolumns most of the antibodies were adsorbed in a narrow band at or near the column's entrance. The latter situation would give the label and target a much shorter contact time with the antibodies and may have decreased the apparent 
amount of antibodies that were encountered by these two competing agents in the column. Such an effect could have produced a sharper increase in the response at low target concentrations. The expected result would be similar to the differences in response that were observed earlier when comparing the calibration curves for the solution- and column-based simultaneous injection assays in Fig. 5.

\section{Conclusion}

This study examined the use of affinity microcolumns that contained immobilized protein $\mathrm{G}$ as general platforms for creating chromatographic-based competitive binding immunoassays for protein biomarkers. HSA was used as a model target for this work and the label was HSA that contained a near infrared fluorescent dye. Protein G microcolumns were made with dimensions of $2.1 \mathrm{~mm}$ i.d. $\times 5 \mathrm{~mm}$ that had binding capacities of around $0.067 \mathrm{mg} \mathrm{IgG}$ and that could be used at flow rates of $0.10-1.0 \mathrm{~mL} / \mathrm{min}$ with back pressures of 50 psi or less. In addition, these microcolumns had an average capture efficiency of $92 \%$ at $0.10 \mathrm{~mL} / \mathrm{min}$ for the typical amounts of antibodies that were later used with these columns in various competitive binding assays.

The assay formats that were examined included a solution-based simultaneous injection method, as well as column-based simultaneous injection and sequential injection formats. The same amounts of label and antibodies were used per sample in each technique, as chosen for the analysis of a protein target in the low-to-mid ng/mL range. The analytical properties that were obtained in these assays are summarized in Table 1, with all of these particular methods giving detection limits in the range of $8-19 \mathrm{ng} / \mathrm{mL}$. Although the responses and detection limits that were noted in this study may vary as other types of antibodies, targets and labeling methods are used in these formats, the results in Table 1 do demonstrate several general trends that should 
apply to all such assays. For instance, the column-based sequential injection immunoassay provided the best limit of detection and the greatest change in response at low target concentrations. The precision of the two column-based methods was slightly better than the precision of the solution-based method (i.e., $\pm 5 \%$ versus $\pm 10 \%$ ), but the solution-based method had broader linear and dynamic ranges. The solution-based method required a pre-incubation step for the antibodies with the label and sample, which was not needed in the column-based methods. However, the solution-based method also had the possibility of being used for multiple injections during each analysis cycle. It was further noted that the assays based on antibodies adsorbed to protein $\mathrm{G}$ microcolumns gave lower detection limits than would be expected for the same types of assays when using columns with a uniform distribution of covalently immobilized antibodies.

These results provide valuable guidelines that can be used in future work to choose between these various formats and in the use of protein $G$ microcolumns for these assays. Various factors that can affect and be controlled in these assays were also identified, which should be useful in the development of new applications for these techniques. This present study builds on prior work that has used immobilized antibodies in affinity microcolumns for other assay formats (e.g., a one-site immunometric assay) [29], and further extends the range of applications that can be assessed by using such columns in chromatographic immunoassays. The use of protein $\mathrm{G}$ microcolumns in these and other formats is not limited to HSA but could be extended to other proteins, biomarkers or targets of clinical or pharmaceutical interest. All that is required is the use of an appropriate antibody for the given target and a labeled analog that can compete with this target for its antibodies. It is expected that protein $\mathrm{G}$ microcolumns and these methods should be of great future interest with the growing demand for methods and 
miniaturized devices in* which antibodies and immunoassays can be employed for the rapid analysis of specific target compounds.

\section{Acknowledgements}

This work was supported, in part, by the National Institutes of Health under grant R01 GM044931 and by the National Science Foundation/EPSCoR program under grant EPS1004094. Support for the remodeled facilities that were used to perform these experiments was provided under NIH grant RR015468-001.

\section{References}

[1] D. Wild (Ed.), The Immunoassay Handbook: Theory and Applications of Ligand Binding, ELISA and Related Techniques, $4^{\text {th }}$ ed. Elsevier, Amsterdam, 2013.

[2] I.A. Darwish, Immunoassay methods and their applications in pharmaceutical analysis: basic methodology and recent advances, Int. J. Biomed. Sci. 2 (2006) 217-235.

[3] D.S. Hage, Immunoassays, Anal. Chem. 71 (1999) 294R-304R.

[4] J.E. Butler (Ed.), Immunochemistry of Solid-Phase Immunoassay. CRC Press, Boca Raton, 1991.

[5] T.M. Phillips, High performance immunoaffinity chromatography. An introduction, LC Mag. 3 (1985) 962-972.

[6] M. de Frutos, F.E. Regnier, Tandem chromatographic-immunological analyses, Anal. Chem. 65 (1993) 17A-25A.

[7] M.G. Weller, Immunochromatographic techniques - a critical review, Fres. J. Anal. Chem. 366 (2000) 635-645.

[8] D.S. Hage, M.A. Nelson, Chromatographic immunoassays. Anal. Chem. 73 (2001) 198A-205A. 
[9] D.S. Hage, T.M. Phillips, Immunoaffinity chromatography. In: Handbook of Affinity Chromatography, $2^{\text {nd }}$ ed. D.S. Hage (Ed.). Taylor \& Francis, New York, 2006, Chapter 6.

[10] A. Moser, D.S. Hage, Chromatographic immunoassays. In: Handbook of Affinity Chromatography, $2^{\text {nd }}$ ed. D.S. Hage (Ed.). Taylor \& Francis, New York, 2006, Chapter 29.

[11] A.C. Moser, D.S. Hage, Immunoaffinity chromatography: an introduction to applications and recent development, Bioanalysis 4 (2010) 769-790.

[12] G.T. Hermanson, A.K. Mallia, P.K. Smith, Immobilized Affinity Ligand Techniques. Academic Press, Boca Raton, 1992.

[13] L. Bjorck, G. Kronvall, Purification and some properties of streptococcal protein G, a novel IgG-binding reagent, J. Immunol. 133 (1984) 969-974.

[14] D.S. Hage, M. Bian, R. Burks, E. Karle, C. Ohnmacht, C. Wa, Bioaffinity chromatography. In: Handbook of Affinity Chromatography, $2^{\text {nd }}$ ed. D.S. Hage (Ed.). Taylor \& Francis, New York, 2006, Chapter 5.

[15] A.J. Jackson, E.M. Karle, D.S. Hage, Preparation of high-capacity supports containing protein G immobilized to porous silica, Anal. Biochem. 406 (2010) 235-237.

[16] J. Turkova, Oriented immobilization of biologically active proteins as a tool for revealing protein interactions and function, J. Chromatogr. B 722 (1999) 11-31.

[17] L.J. Cole, R.T. Kennedy, Selective preconcentration for capillary zone electrophoresis using protein G immunoaffinity capillary chromatography, Electrophoresis 16 (1995) 549-556. 
[18] H. Shen, C.A. Aspinwall, R.T. Kennedy, Dual microcolumn immunoassay applied to determination of insulin secretion from single islets of Langerhans and insulin in serum, J. Chromatogr. B 689 (1997) 295-303.

[19] M. de Frutos, S.K. Paliwal, F.E. Regnier, Liquid chromatography based enzymeamplified immunological assays in fused-silica capillaries at the zeptomole level, Anal. Chem. 65 (1993) 2159-2163.

[20] E.G. Vlakh, G.A. Platonova, T.B. Tennikova, Affinity chromatography of proteins on monolithic columns, Meth. Mol. Biol. 1129 (2014) 303-324.

[21] T.B. Tennikova, R. Freitag, An introduction to monolithic disks as stationary phases for high performance biochromatography, J. High Res. Chromatogr. 23 (2000) 27-38.

[22] E. Turiel, P. Fernandez, C. Perez-Conde, A.M. Gutierrez, C. Camara, Flow-through fluorescence immunosensor for atrazine determination, Talanta 47 (1998) 1255-1261.

[23] U.J. Meyer, Z.L. Zhi, M. Meusel, F. Spener, E. Loomans, Automated stand-alone flow injection immunoanalysis system for the determination of cephalexin in milk, Analyst 124 (1999) 1605-1610.

[24] T.M. Phillips, Microanalytical methods based on affinity chromatography. In: Handbook of Affinity Chromatography, $2^{\text {nd }}$ ed., D.S. Hage (Ed.). Taylor \& Francis, New York, 2006, Chapter 28.

[25] W. Clarke, A.R. Choudhuri, D.S. Hage, Analysis of free drug fractions by ultra-fast immunoaffinity chromatography, Anal. Chem. 73 (2001) 2157-2164.

[26] C.M. Ohnmacht, J.E. Schiel, D.S. Hage, Analysis of free drug fractions using near infrared fluorescent labels and an ultrafast immunoextraction/displacement assay, Anal. Chem. 78 (2006) 7547-7556. 
[27] A.C. Moser, C.W. Willicott, D.S. Hage, Clinical applications of capillary electrophoresisbased immunoassays, Electrophoresis 35 (2014) 937-955.

[28] J.E. Schiel, Z. Tong, C. Sakulthaew, D.S. Hage, Development of a flow-based ultrafast immunoextraction and reverse displacement immunoassay: analysis of free drug fractions. Anal. Chem. 83 (2011) 9384-9390.

[29] E.L. Pfaunmiller, J.A. Anguizola, M.L. Milanuk, E. Papastavros, N. Carter, R. Matsuda, X. Zheng, D.S. Hage, Development of microcolumn-based one-site immunometric assays for protein biomarkers, J. Chromatogr. A 1366 (2014) 92-100.

[30] T.M. Phillips, Multi-analyte analysis of biological fluids with a recycling immunoaffinity column array, J. Biochem. Biophys. Methods 49 (2001) 253-262.

[31] T. Jiang, R. Mallik, D.S. Hage, Affinity monoliths for ultrafast immunoextraction, Anal. Chem. 77 (2005) 2362-2372.

[32] W. Clarke, J.E. Schiel, A. Moser, D.S. Hage, Analysis of free hormone fractions by an ultrafast immunoextraction/displacement immunoassay: studies using free thyroxine as a model system, Anal. Chem. 77 (2005) 1859-1866.

[33] D.S. Hage, R.R. Walters, H.W. Hethcote, Split-peak affinity chromatographic studies of the immobilization-dependent adsorption kinetics of protein A, Anal. Chem. 58 (1986) 274-279.

[34] D.S. Hage, R.R. Walters, Dual-column determination of albumin and immunoglobulin G in serum by high-performance affinity chromatography, J. Chromatogr. 386 (1987) 3749.

[35] X. Ren, Flow injection fluoroimmunoassay for human transferrin using a protein A immunoreactor, Anal. Lett. 27 (1994) 1067-1074.

[36] D.A. Palmer, M. Evans, J.N. Miller, M.T. French, Rapid fluorescence flow injection 
immunoassay using a novel perfusion chromatographic material, Analyst 119 (1994) 943-947.

[37] C.M. Rico, M.D. Fernandez, A.M. Gutierrez, M.C.P. Conde, C. Camara, Development of a flow fluoroimmunosensor for determination of theophylline, Analyst 120 (1995) 25892591.

[38] X. Zheng, Z. Li, S. Beeram, R. Matsuda, E.L. Pfaunmiller, M. Podariu, C.J. White II, N. Carter, D.S. Hage, Analysis of biomolecular interactions using affinity microcolumns: a review, J. Chromatogr. B 968 (2014) 49-63.

[39] L. Middendorf, J. Amen, R. Bruce, D. Draney, D. DeGraff, J. Gewecke, D. Grone, P. Humphrey, G. Little, A. Lugade, N. Narayanan, A. Oommen, H. Osterman, R. Peterson, J. Rada, R. Raghavachari, S. Roemer, S. Daehne (Eds.), Near-Infrared Dyes for High Technology Applications, Kluwer Academic, Netherlands, 1998.

[40] G. Patonay (Ed.), HPLC Detection - Newer Methods. VCH, New York, 1993.

[41] P.K. Smith, R.I. Krohn, G.T. Hermanson, A.K. Mallia, F.H. Gartner, M.D. Provenzano, E.K. Fujmoto, N.M. Goeke, B.J. Olson, D.C. Klenk, Measurement of protein using bicinchoninic acid, Anal. Biochem. 150 (1985) 76-85.

[42] J.A. Anguizola, Ph.D. Dissertation, University of Nebraska, Lincoln, 2013.

[43] D.S. Hage, R.R. Walters, Non-linear elution effects in split-peak chromatography. I. Computer simulations for the cases of irreversible diffusion- and adsorption-limited kinetics, J. Chromatogr. 436 (1988) 111-135.

[44] J.G. Rollag, D.S. Hage, Non-linear elution effects in split-peak chromatography. 2. Role of ligand heterogeneity in solute binding to columns with adsorption-limited kinetics, J. Chromatogr. A 795 (1998) 185-198. 
[45] M.A. Nelson, W.S. Reiter, D.S. Hage, Chromatographic competitive binding immunoassays: a comparison of the sequential and simultaneous injection methods, Biomed. Chromatogr. 17 (2003) 188-200.

[46] D.S. Hage, D.H. Thomas, A.R. Chowdhuri, W. Clarke, Development of a theoretical model for chromatographic-based competitive binding immunoassays with simultaneous injection of sample and label, Anal. Chem. 71 (1999) 2965-2975.

[47] M. Lee, R.A. Durst, R.B. Wong, Comparison of liposome amplification and fluorophor detection in flow-injection immunoanalyses, Anal. Chim. Acta 354 (1997) 23-28.

[48] N. Kaneki, Y. Xu, A. Kumari, H.B. Halsall, W.R. Heineman, P.T. Kissinger, Electrochemical enzyme immunoassay using sequential saturation technique in a $20-\mu \mathrm{L}$ capillary: digoxin as a model analyte, Anal. Chim. Acta 287 (1994) 253-258.

[49] P. Kramer, R. Schmid, Flow injection immunoanalysis (FIIA) - a new immunoassay format for the determination of pesticides in water, Biosens. Bioelectron. 6 (1991) 239243.

[50] M. Nilsson, H. Haakanson, B. Mattiasson, Process monitoring by flow-injection immunoassay: evaluation of a sequential competitive binding assay, J. Chromatogr. 597 (1992) 383-389.

[51] D.S. Hage, D.H. Thomas, M.S. Beck, Theory of a sequential addition competitive binding immunoassay based on high-performance immunoaffinity chromatography, Anal. Chem. 65 (1993) 1622-1630. 


\section{Figure Legends}

Figure 1. Scheme for the use of a protein G microcolumn in a solution-based simultaneous injection immunoassay.

Figure 2. Scheme for the use of a protein $\mathrm{G}$ microcolumn in a column-based simultaneous injection immunoassay

Figure 3. Scheme for the use of a protein G microcolumn in a column-based sequential injection immunoassay

Figure 4. Typical chromatograms and non-retained peaks obtained for labeled HSA in a column-based sequential injection immunoassay at an injection flow rate of 0.10 $\mathrm{mL} / \mathrm{min}$. The concentrations that are listed represented the unlabeled HSA in the samples that were injected prior to a fixed amount of the labeled HSA. Both the samples and labeled HSA were injected onto a protein G microcolumn that contained previously adsorbed anti-HSA antibodies. The time scale for these chromatograms is shown at the bottom of the figure. The set of double diagonal lines at the bottom represent the time intervals over which an elution and regeneration step, along with the application of the antibodies and the sample to the protein $\mathrm{G}$ microcolumn, were carried out prior to injection of the labeled HSA.

Figure 5. Calibration plots for (a) a solution-based simultaneous injection immunoassay, (b) a column-based simultaneous injection immunoassay, and (c) a column-based sequential injection immunoassay for HSA that were each conducted on $2.1 \mathrm{~mm}$ i.d. $\times 5 \mathrm{~mm}$ protein $\mathrm{G}$ microcolumns using anti-HSA antibodies. The conditions 
are given in the text. These results are based on the measured height, or amplitude, due to the labeled HSA (or "label") that was present in the nonretained peak. The error bars represent \pm 1 standard error of the mean $(n=3)$.

Figure 6. Effects of antibody concentration on the response of a solution-based simultaneous injection immunoassay using anti-HSA antibodies and a $2.1 \mathrm{~mm}$ i.d. $\times 5 \mathrm{~mm}$ protein $\mathrm{G}$ microcolumn. These samples contained various concentrations of anti-HSA antibodies $(1.67 \mu \mathrm{g} / \mathrm{mL}, \circ ; 16.7 \mu \mathrm{g} / \mathrm{mL}, \boldsymbol{\Delta} ; 134 \mu \mathrm{g} / \mathrm{mL}, \bullet)$ that were mixed with a fixed amount $(1200 \mathrm{ng} / \mathrm{mL})$ of near infrared fluorescent labeled HSA in a 15:1 (v/v) ratio and incubated for 30 min prior to injection. A series of $50 \mu \mathrm{L}$ injections were then made for each mixture at $0.10 \mathrm{~mL} / \mathrm{min}$, with no elution step being used between injections. 
Table 1. Comparison of the analytical properties of several competitive binding immunoassay formats carried out on protein G microcolumns

\begin{tabular}{|c|c|c|c|c|c|}
\hline Type of Assay & $\begin{array}{c}\text { Assay Range } \\
(\mathrm{ng} / \mathrm{mL})^{\mathrm{a}}\end{array}$ & $\begin{array}{c}\text { Assay Time } \\
\left(_{(\min )^{b}}\right.\end{array}$ & Precision & Advantages & Disadvantages \\
\hline $\begin{array}{l}\text { Solution-based } \\
\text { simultaneous } \\
\text { injection } \\
\text { immunoassay }\end{array}$ & $\begin{array}{l}\text { Linear range: } \\
19 \text { to } 225 \\
\text { Dynamic range: } \\
19 \text { to } 400\end{array}$ & $34-35$ & $\pm 10 \%$ & $\begin{array}{c}\text { Can allow injection } \\
\text { of multiple samples } \\
\text { per cycle; } \\
\text { relatively broad } \\
\text { linear \& dynamic } \\
\text { ranges }\end{array}$ & $\begin{array}{c}\text { Requires pre- } \\
\text { incubation step; } \\
\text { highest limit of } \\
\text { detection for these } \\
\text { methods }\end{array}$ \\
\hline $\begin{array}{l}\text { Column-based } \\
\text { simultaneous } \\
\text { injection } \\
\text { immunoassay }\end{array}$ & $\begin{array}{l}\text { Linear range: } \\
13 \text { to } 75-80 \\
\text { Dynamic range: } \\
13 \text { to }>250\end{array}$ & $7-10$ & $\pm 5 \%$ & $\begin{array}{l}\text { Does not require a } \\
\text { pre-incubation } \\
\text { step; relatively fast } \\
\text { for individual } \\
\text { samples }\end{array}$ & $\begin{array}{l}\text { Moderate linear and } \\
\text { dynamic ranges; } \\
\text { intermediate limit of } \\
\text { detection }\end{array}$ \\
\hline $\begin{array}{l}\text { Column-based } \\
\text { sequential } \\
\text { injection } \\
\text { immunoassay }\end{array}$ & $\begin{array}{l}\text { Linear range: } \\
7.9 \text { to } 50 \\
\text { Dynamic range: } \\
7.9 \text { to } 150\end{array}$ & $10.5-15$ & $\pm 5 \%$ & $\begin{array}{l}\text { Does not require } \\
\text { pre-incubation } \\
\text { step; moderately } \\
\text { fast for single } \\
\text { samples; lowest } \\
\text { limit of detection }\end{array}$ & $\begin{array}{l}\text { Narrow linear and } \\
\text { dynamic range; } \\
\text { elution \& } \\
\text { regeneration } \\
\text { required between } \\
\text { samples }\end{array}$ \\
\hline
\end{tabular}

${ }^{a}$ The first value given in each range is the lower limit of detection at $S / N=3$.

${ }^{\mathrm{b}}$ These are the elapsed times at an application flow rate of $0.10 \mathrm{~mL} / \mathrm{min}$ that span from the initial contact of the sample with the antibodies, or the application of the antibodies to the protein $\mathrm{G}$ column, to the time when the non-retained peak for the injection of the labeled target analog is detected and measured. Additional time in each method is required for the elution and regeneration of the protein $\mathrm{G}$ column after each series of injections. 
Step 1: Incubate labeled analog (label) + analyte + antibody

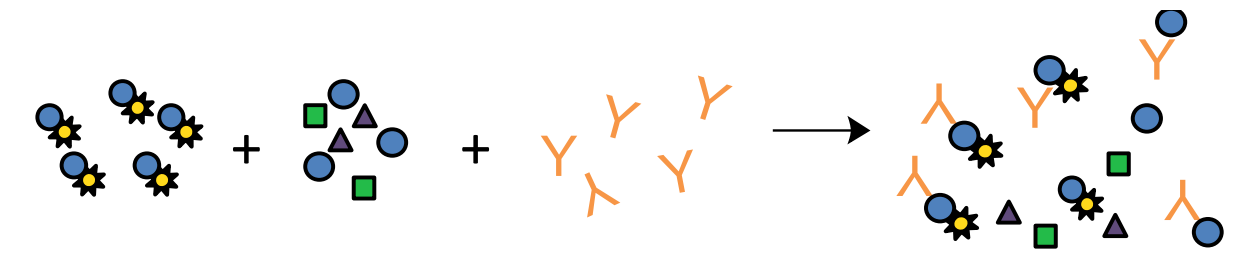

Step 2: Inject mixture onto column containing immobilized protein $\mathrm{G}$

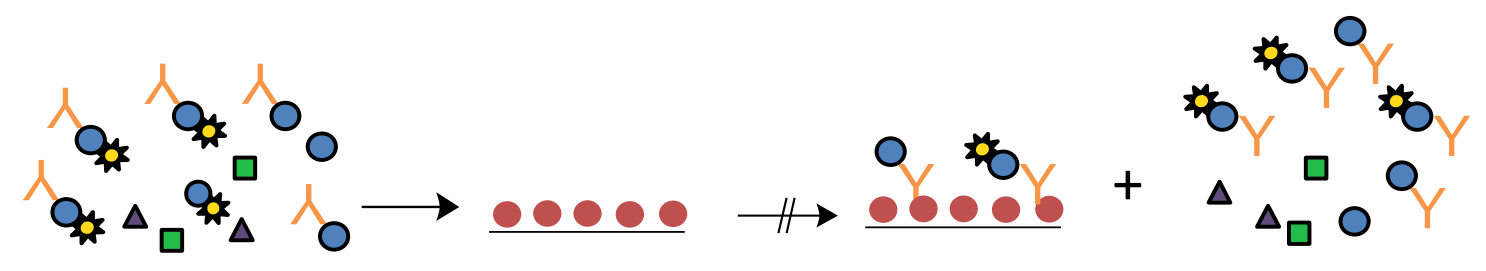

Step 3: Elute retained compounds, apply initial buffer \& regenerate column

$$
\begin{aligned}
& \text { Elution } \\
& \text { buffer }
\end{aligned}
$$

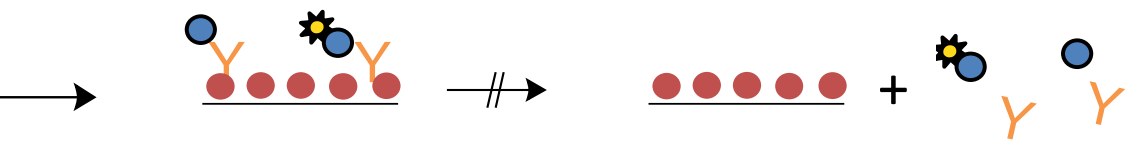

$$
\begin{aligned}
& \mathrm{O}=\text { Target }=\text { Label } Y=\text { Antibody } \quad \text {, } \Delta=\text { Non-retained } \\
& \text { sample components }
\end{aligned}
$$

\section{Figure 1}


Step 1: Inject antibody onto column containing immobilized protein $G$

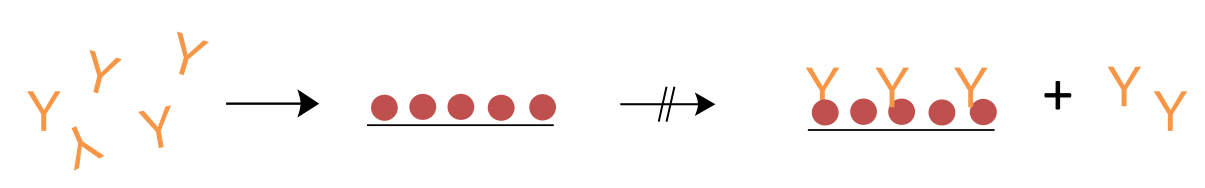

Step 2: Mix sample with label and inject onto protein G column containing adsorbed antibodies

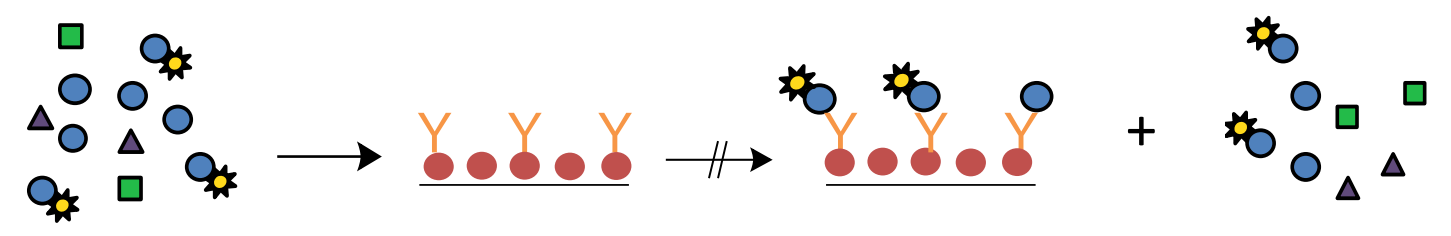

Step 3: Elute retained compounds, apply initial buffer \& regenerate column

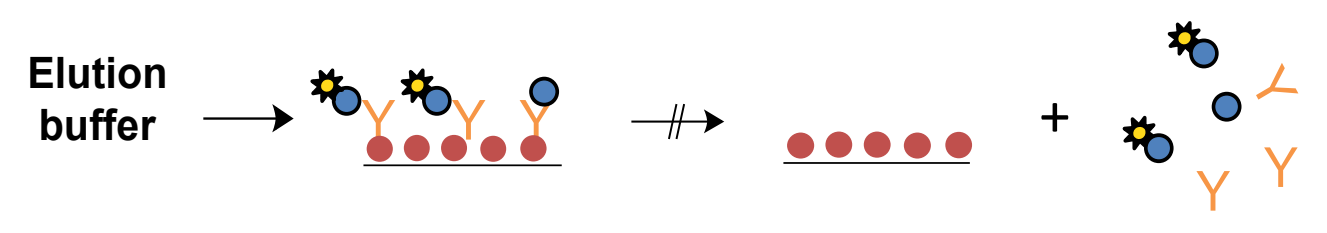

$$
\begin{aligned}
& O=\text { Target }=\text { Label } Y=\text { Antibody } \quad \square, \Delta=\text { Non-retained } \\
& \text { sample components }
\end{aligned}
$$

Figure 2 
Step 1: Inject antibody onto column containing immobilized protein $\mathrm{G}$

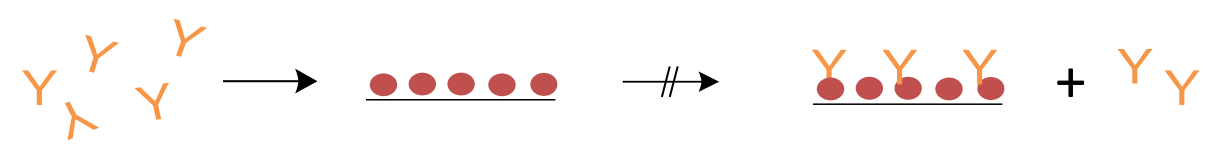

Step 2: Inject sample onto protein G column containing adsorbed antibodies

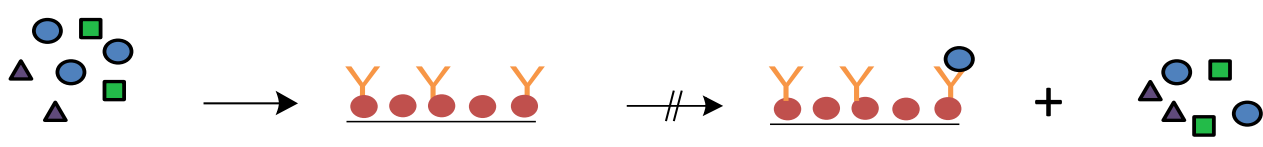

Step 3: Inject sample onto protein G column containing adsorbed antibodies

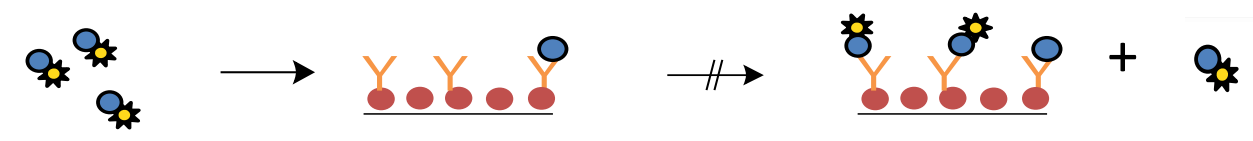

Step 4: Elute retained compounds, apply initial buffer \& regenerate column

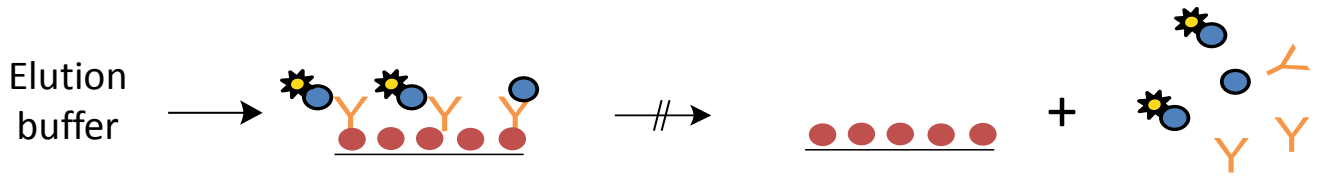

$$
O=\text { Target }=\text { Label } Y=\text { Antibody } \begin{array}{r}
\square, \Delta= \\
\text { sample components }
\end{array}
$$

\section{Figure 3}




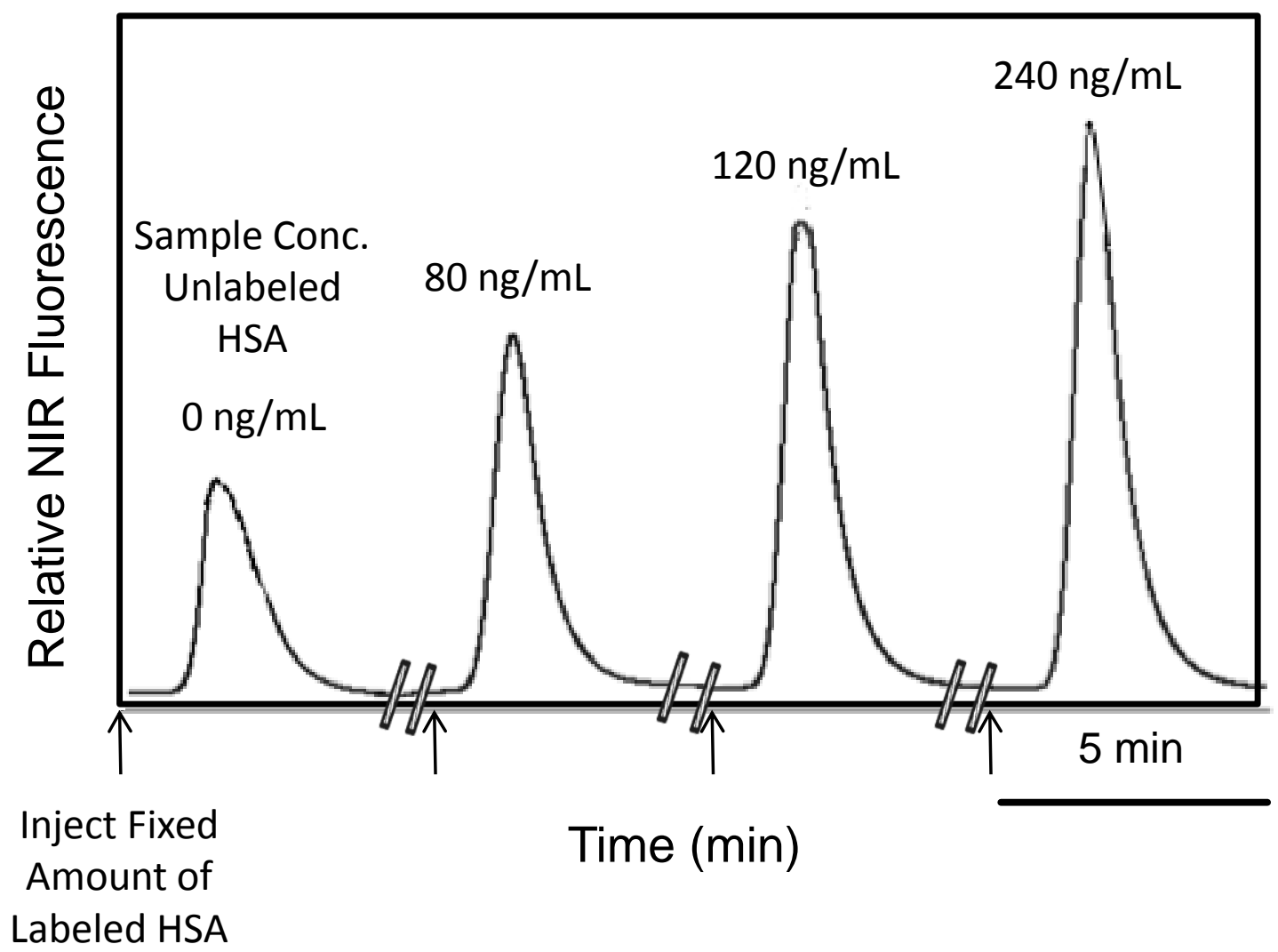

Figure 4 


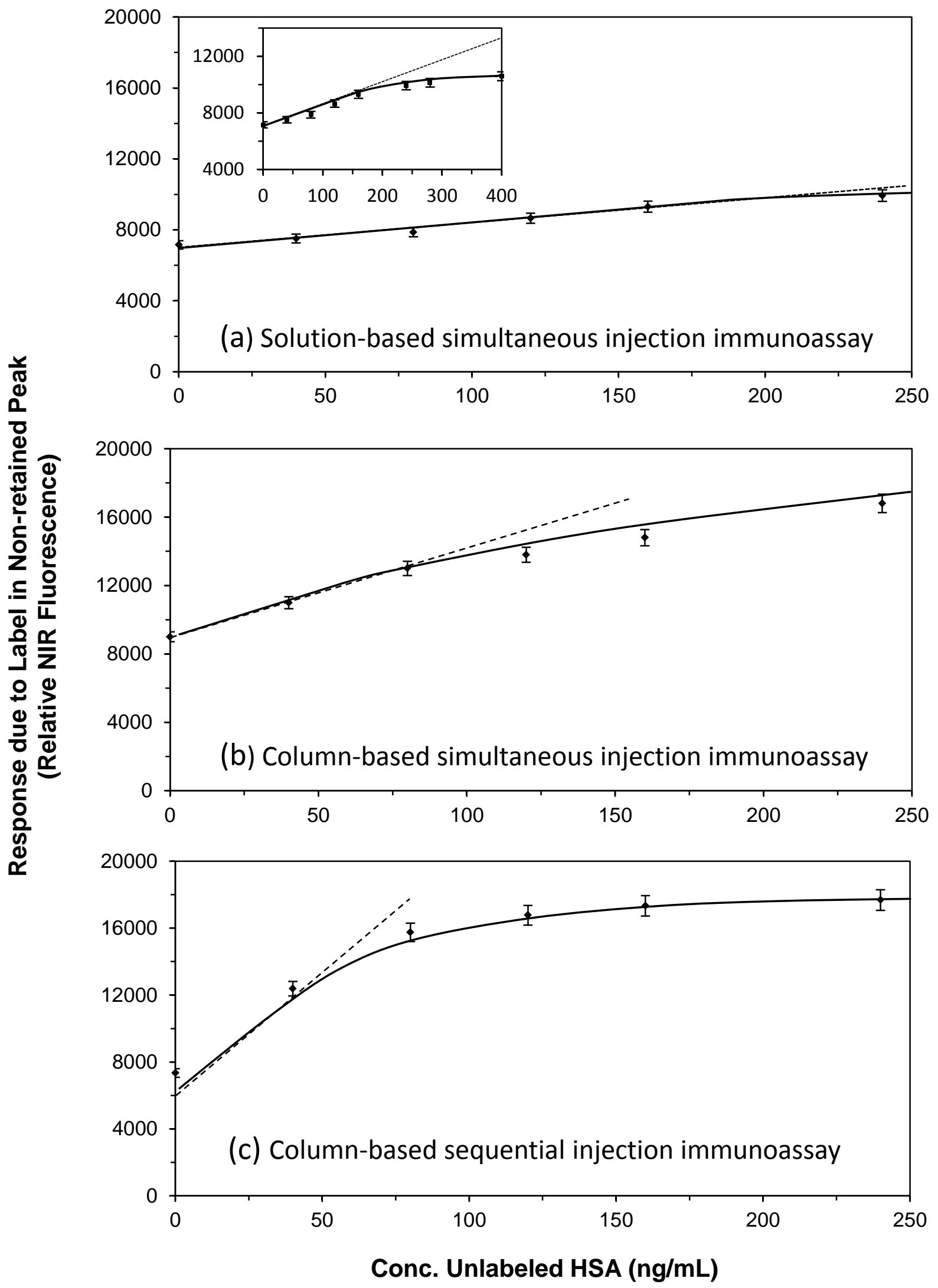

Figure 5 


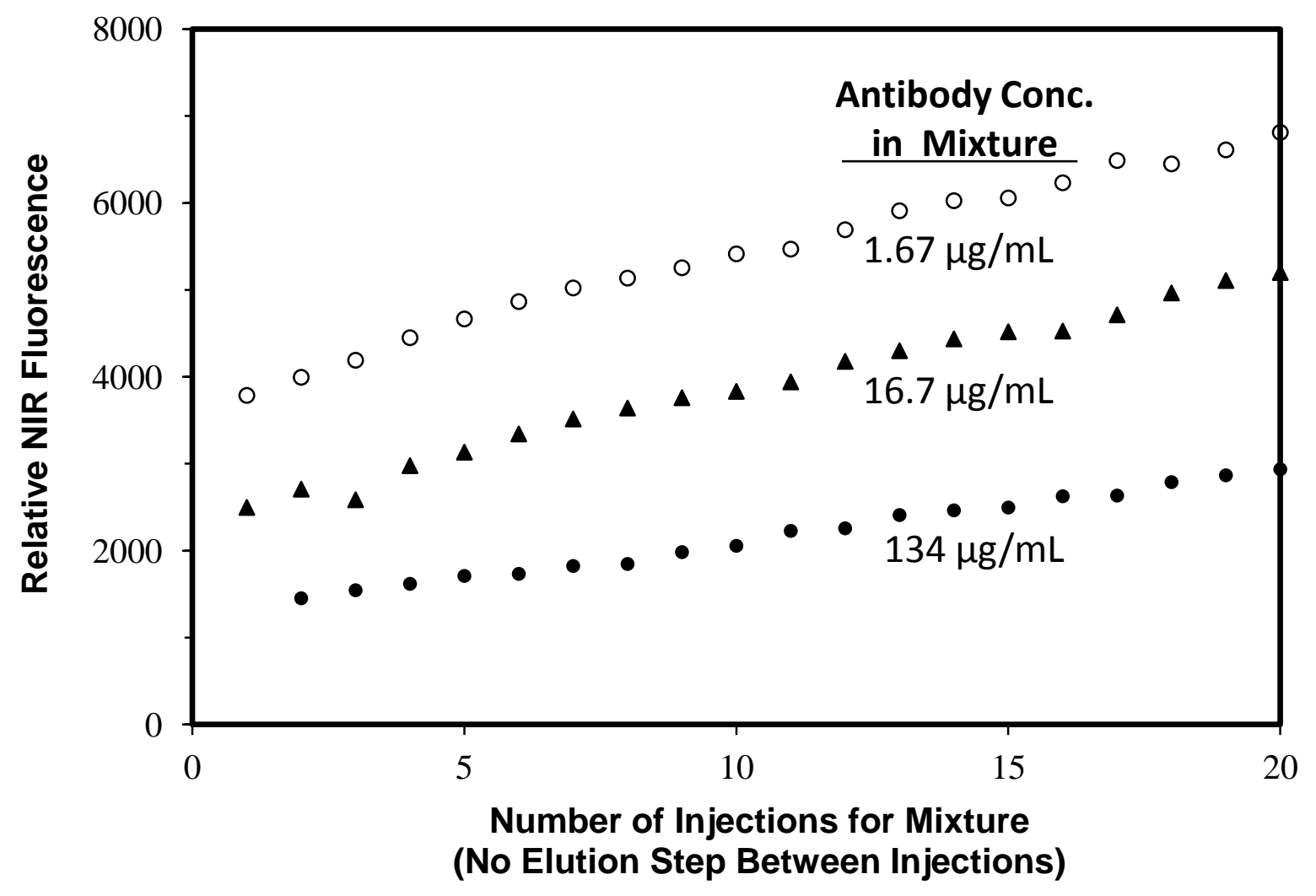

Figure 6 